\title{
THE LABOUR INJUNCTION IN ALBERTA
}

\begin{abstract}
KENNETH P. SWAN*
In the last issue of the Alberta Law Review. Professor Innis Christie dealt with the substantive law of picketing in Alberta. In this article, the writer examines the procedural aspects of the labour injunction in Alberta and makes recommendations for reform of the law. In addition to reported cases from Alberta and elsewhere, a number of unreported cases from the Province are discussed and related to the development of the law of labour injunctions.
\end{abstract}

The jurisdiction of this Court is to protect property, and it will interfere by injunction to stay any proceedings, whether connected with crime or not, which go to the immediate, or tend to the ultimate, destruction of property, or make it less valuable or comfortable for use or occupation. ...

In the present case the acts complained of are illegal and criminal by the Act of Geo. 4, and it is admitted by the demurrers that they were designedly done as part of a scheme, by threats and intimidation, to prevent persons from accepting work from the Plaintiffs, and, as a consequence, to destroy the value of the Plaintiffs' property ..... In the meantime I would only make this observation, that by the Act of Parliament it is recited that all such proceedings are injurious to trade and commerce, and dangerous to the security and personal freedom of individual workmen, as well as to the security of the property and persons of the public at large; and if it should turn out that this Court has jurisdiction to prevent these misguided and misled workmen from committing these acts of intimidation, which go to the destruction of that property which is the source of their own support and comfort in life, I can only say that it will be one of the most beneficial jurisdictions ever exercised.

With these words Vice-Chancellor Malins marked the entry of the Courts of Equity into the arena of industrial conflict with the formidable injunction for a weapon.' One might have thought that after a century of progress in the law of industrial relations, a century in which the Act of George 4 was repealed," and the right of workers to combine for their mutual benefit was established, that no court of equitable jurisdiction would consider itself today bound to exercise that jurisdiction to protect organized labour from itself. Yet the history of the use of the labour injunction in Alberta in recent years reveals that the spirit of the Vice-Chancellor's judgment lingers on, though the letter of the law which he expressed has long been dead. In many cases, as will be seen, the anxiety of the Courts to avoid any whisper of confrontation or the slightest peril to property (in the most abstract sense of that term) has been given precedence over the policy implicit in the Alberta Labour Act" and the modern view of industrial relations as a resolution of conflicting interests through the application of economic pressure. The object of this article is to demonstrate that the injunction, while essential to the rule of law in our society, may through misuse become the instrument by which the rule of law is subverted to a system of rule by the Courts.

It has been said that if the labour injunction did not exist, it would have to be invented. ${ }^{4}$ The fact is that it was invented, created by the equity courts to meet a challenge to the principle of private property

- B.Eng. (R.M.C.), LL.B., (Alta.), Graduate Student, London School of Economics and Polltical Science.

I Springhead Spinning Company v. Riley (1868) L.R. 6 Eq. 551 at 562-563.

3 The Combination Act, 1825 (U.K.). repealed by The Criminal Law Amendment Act, 1871 .

\# R.S.A. 1955 , c. 167 , as amended.

1 Lambert: The Use of the Civil Injunction in Labour Disputes, [1969] Can. Bar Papers 169 at 172 . 
that had no redress in the common law. The equity injunction was developed to protect property and property rights in situations where damages would not be a sufficient remedy for the loss incurred, and was eventually extended as an interlocutory proceeding to protect property on an interim basis or to preserve the status quo until the trial of an action. The labour injunction in Alberta today is for all practical purposes exclusively an interlocutory remedy. Very few cases ever come on for trial for a final determination of the dispute; in the typical case, even where the dispute still exists at the time when the matter could come to trial, the action is adjourned or abandoned to prevent any embarrassment to the negotiations in progress to settle the strike. In the result, the injunction is less an instrument for the protection of a property right until final judgement on that right than another weapon in the economic warfare surrounding an industrial dispute.

It is a very effective weapon, ideally suited to the dynamics of industrial conflicts. An injunction, if sought as an interim measure in interlocutory proceedings, is quick, inexpensive and effective. If abandoned before final determination, it provides a means of exerting economic pressure without any ultimate justification by trial according to law. It provides a simple method of circumventing the vagaries and anachronisms of the criminal law and of the law of tort, and replacing them with a codification of proscribed acts and conduct enforceable by the swift and sure penal sanctions derived from the jurisdiction in personam of a court of Equity. It provides a meaningful sanction against unions and individual workers against whom large damage awards would be impossible of execution. No wonder that, since the Courts have made the remedy available, it is resorted to in almost every appropriate case.

No wonder either, considering the effectiveness of the remedy and its greater utility as a weapon when used by management against labour, that the injunction has been the target of a massive informational and political campaign by organized labour directed toward the abolition of the injunction in labour disputes." The labour movement views the injunction as a strikebreaking tool, by the use of which management is able to enlist the Court as an ally in the struggle against a striking union. There can be little doubt that, in the view of organized labour, the injunction represents an abuse of the judicial process when used in an industrial dispute; this widely-held view does little to increase public respect for the Courts and for the law. This article will explore the procedural aspects of the injunction to determine the extent to which labour is justified in its enmity and the means by which the law might be reformed. It is not intended to make an exhaustive study of the substantive law of picketing, but since injunctions are most often granted to restrain picketing, some reference to substance will be necessary."

\section{Ex Parte Injunctions}

One of the major criticisms levelled by labour at the injunction is directed to the availability, in many jurisdictions, of injunctive relief

- The Campaign Against Injunctions: The Canadian Labour Conoress, (1966) 11 Can. Lab. 5/38: Get Rid of the Injunction, (1967) 12 Can. Lab. 2/21.

a For a recent treatment of the substantive law see I. Christie. The Law of Picketing in Alberta. (1970) 8 Alta. L.R. 342. 
on an ex parte application. This procedure will not be repugnant to lawyers, for in appropriate cases of all types where there is some urgency, interim injunctions are often granted ex parte. The order is always returnable, and an application to vary may be made on notice at any time. To labour leaders, however, the procedure is anathematic. They see such an order as an unfair restraint on their right to picket, obtained behind their backs before a Court to which they could make no representations. Moreover, in many cases the damage to the union's ability to wage the economic contest will often have been sufficient to determine the outcome of the dispute in favour of management by the time that proceedings can be taken to lift an injunction wrongly granted ex parte.

The labour view of ex parte proceedings is a very reasonable one, supported by cogent legal arguments. It is very seldom that justice will be done in any case in the absence of parties; that principle is at the very foundation of our adversary system. $E x$ parte proceedings are an invitation to exaggerated pleadings and distorted evidence, for they allow of no contradiction or testing by cross-examination. Further, they increase the possibility of judicial error in the law, for the judge is forced to come to a decision without the benefit of argument on both sides of the issue. Finally, such proceedings, in an area of the law where it is well known that the immediate effect of the injunction is the important effect, and that subsequent motions to vacate an injunction may be only of academic interest if they succeed in vindicating the position of the enjoined party after it is too late to be of any practical value, are at least theoretically a denial of natural justice. The maxim audi alteram partem, if it is to mean anything at all, must mean that both sides must be heard at some stage in the proceedings when there are still some matters of substance to be argued. If the first hearing is to be the one in which all the decisions which will have any substantial effect on the outcome of the dispute are made, then both parties must be present at that hearing if justice is to be done. It is submitted that these circumstances obtain in almost every labour injunction case.

The principle has been recognized by the Alberta Legislature, which is a pioneer in this area of labour law. Although ex parte injunctions are still available in labour disputes in many Canadian jurisdictions, they have been, at least theoretically, prohibited in Alberta since 1960. The treatment accorded by the Courts to this express direction not to hear injunction applications ex parte is most instructive; a study of some of the unreported cases indicates a complete disregard for the policy implicit in the legislative enactment and even for the express words of the statute.

In 1960 , section $24 a$ was added' to the Judicature Act.' In its original form, this section provided:

"24a. Notwithstanding the provisions of this Act or any other Act of the province where a strike or lockout exists in a labour dispute to which the Alberta Labour Act applies, no injunction before trial shall be granted ex parte, to restrain any person from doing any act with respect to the strike or lockout."

In 1965, the meaning of that section was at issue before Riley $J$. of the Alberta Supreme Court on a motion to continue an ex parte injunction

i S. A. 1960 , c. 53 , s. 2.

R.S.A. 1955, c. 164. 
granted by a District Court Judge in Lethbridge. The case was Nichol et al. v. MacLaren et al," where an injunction had been sought to restrain picketing of a hotel on the ground that businesses in the hotel, a restaurant and a barber shop, were being injured by picketing conducted by the striking hotel employees. Both of these businesses were legal entities separate from the hotel company. On the issue whether the injunction was invalid as not conforming to the requirement for notice in S. 24a of the Judicature Act, Riley J. noted:

1. That the plaintiffs were not parties to the dispute.

2. No labour dispute exists between the plaintiffs and the defendants.

3. The plaintiffs are, so to speak, innocent parties to the labour dispute and innocent bystanders.

4. As between the plaintiffs and the defendants, the defendant Union has no rights to protect. There is little doubt that the public, in the result, are being persuaded or perhaps intimidated to withdraw patronage from the said businesses.

With respect, the learned Judge was wrong to rely on these four points to dispose of the question of $\mathrm{s}$. 24a, as he seems to have done. It is difficult to see the relevance of some of these points, and the rest of them fly in the face of the express words of the statute. The section requires the existence of a strike or lockout in a labour dispute to which the Labour Act applies. Once that condition is met, no person may be restrained ex parte from doing an act with respect to the strike or lockout. It is impossible to see how Riley J. could read that section to require the paintiff to be a party to the dispute in order to attract the section, but that interpretation stood as law in the Province for more than three years.

In 1968, the Legislature amended the Alberta Labour Act" in a further attempt to prohibit ex parte injunctions. Section 94a, which was added at that time, ${ }^{11}$ provided:

Notwithstanding anything in this Act, The Judicature Act or any other

Act, where a lawful strike or lockout exists in a labour dispute, no injunction

before trial shall be granted ex parte to restrain any party to the dispute or any

other person from doing any act in connection with the strike or lockout.

The extent to which this section changes the previous provisions of the Judicature Act is not clear. It adds the word "lawful" before "strike or lockout", an addition the effect of which will be discussed later. It also defines with greater certainty the persons who may not be restrained ex parte. It does not, however, deal with the critical issue, in the light of Nichol v. MacLaren, of the importance of the identity of the plaintiff. Neverthess, it is still impossible to understand how, in the face of the express words of the statute, such an interpretation as that put on s. 24a of the Judicature Act could be put on this section.

On October 18, 1968, two injunctions were granted ex parte against Operating Engineers Union Local 955 in Calgary, in Super $S$ Drugs v. Coutts et al." and Foundation Properties Ltd. v. Coutts et al. ${ }^{13}$ The second of the cases eventually came to an application to vacate the injunction on November 15, 1968. At the hearing, it was argued that $s$. 94a was conclusive of the matter, and that the injunction should never have been granted on an ex parte application. Counsel for the plaintiffs argued that, since in these cases employees of construction companies

Q1965) 51 D.L.R. (2d) 667

10 R.S.A. 1955, c. 167.

11 S.A. 1968, c. 51, s. 27, effective June 1, 1968.

12 Unreported. Supreme Court of Alberta, J.D.C. 94221. Oct. 18, 1968.

13 Unreported. Supreme Court of Alberta, J.D.C. 94236. Oct. 18, 1968. 
were picketing job-sites occupied by businesses not parties to the labour dispute, and since these businesses were the plaintiffs in both actions, Nichol v. MacLaren would apply to oust the section. The issue was left unsettled. Although the grounds for the application to vacate the injunction were set out in the preamble to the order, the order itself dismisses the application because

the lawful strike engaged in by the Defendant Union at the commencement of these proceedings has now been settled and accordingly the circumstances under which the Injunction order was made no longer exist.

The present state of the law is as it was left by these two cases. If Nichol v. MacLaren is still the law in Alberta, then ex parte injunctions may still be available in cases where the plaintiff is not a party to the labour dispute. As a result, a further amendment was made to the Labour Act in 1970.' Section 94a was amended to read as follows:

(1) Notwithstanding anything in this Act, the Judicature Act or any other Act, where a lawful strike or lockout exists in: a labour dispute, no injunction before trial shall be granted ex parte to

(a) a party to the dispute, or

(b) any other person or party,

to restrain any party to the dispute from doing any act in connection with the strike or lockout.

This section clearly overturns Nichol v. MacLaren at last, but it is still open to at least one criticism. In this form the section begs an important question, for, in many injunction applications, the very issue to be determined is whether or not there is a "lawful" strike or lockout. If lawfulness is the point in question, it is possible under the section as it now stands that a determination on the central issue may be made ex parte an an incident of granting an injunction. The excision of this word is essential to the rationalization of the law of labour injunctions. As it now stands, the word "lawful" only provides a device by which the section may be circumvented.

This brief study of ex parte injunctions serves as an excellent illustration of the way in which a judicial attitude unfriendly to labour has been discerned by labour leaders. The Legislature may still not have achieved after three attempts to reform which, on any reasonable view of section 24a of the Judicature Act, it ought to have effected in 1960. Judicial devices to avoid the clear intent of the legislation are the more surprising since no substantive right (such as the property rights so jealously guarded by Equity) was at issue, but merely a procedura] protection designed to assist the administration of justice. The time set for notice in s. 94a (4) of the Labour Act is three hours. It is difficult to imagine any circumstances so extreme that the hearing of an injunction application could not be delayed three hours, or even to imagine circumstances in which any Court could be induced to hear an application in less than three hours, unless these same circumstances would be sufficient to provoke prompt action by the police and civil authorities to stop the acts complained of. In most cases, the desire of any party to have an application heard ex parte can only be a legal tactic designed to avoid facing any defence to the application, and ought to be suspect for that very reason.

In vacating an injunction order made ex parte restraining picketing in Sheftel v. McHardy and Moore, ${ }^{13} \mathrm{Kirby} \mathrm{J}$. is reported by the Calgary 
Herald": as having remarked that the granting of an interlocutory injunction was an extreme remedy and should not be granted unless strongly needed. By logical extension, an ex parte injunction is even more an extreme remedy. Even more forceful are the views of Bence C.J.Q.B. as expressed in Grosvenor Park Shopping Centre v. Cave," where arguments similar to those advanced in Nichol v. MacLaren were used to support an attempt to get an ex parte order in spite of a Saskatchewan statutory provision similar to the Alberta statutes cited above:

It is difficult for me to understand counsel's endeavours to proceed in this manner [i.e., ex parte], even if he thought the provisions of s. 44 para $20(1)$ of the Queen's Bench Act, 1960 (Sask.) c. 35 did not apply. I would venture to say that any judge of this Court would hesitate to hear such a serious matter without giving the respondents an opportunity to be heard.

It is submitted that this is the correct view, and that the Alberta cases which derogate from the statutory provisions requiring notice of labour injunction applications are wrong in law, wrong in principle, and wrong in policy. It is to be hoped that the new Labour Act amendments will prevent any further evasion of the clear intent of the Legislature.

\section{Affidavit Evidence}

A second major criticism of injunction procedure is based on the availability of an injunction on nothing more than affidavit evidence, often based not on personal knowledge but only on information and belief. In the general law of interlocutory applications, there is nothing unusual about affidavit evidence on information and belief:- although the usual rule is that the affidavit shall only include matters within the knowledge of the deponent, an exception is made for interlocutory proceedings."

The danger of such evidence is the impossibility of testing it before the Court by the usual means of cross-examination. Faced only with a sworn statement, the-Court has no opportunity to assess credibility, or to give weight to the evidence according to its source. Where the evidence is given on information and belief, the problem is compounded. Not only is the deponent not before the Court, but the deponent is not even the original source of the evidence. Such evidence is purest hearsay, ordinarily inadmissible. The rationale behind its statutory admissibility is the ease with which, in the ordinary case, an interlocutory order may be overturned on a subsequent application, and the necessity to make such orders readily obtainable without the necessity of collecting large numbers of affidavits or witnesses. None of this applies to the labour injunction, in which, as has been noted above, the first application is often the only hearing on the issues, because the dynamics of the situation require those issues to be resolved for once and all.

This problem has also been recognized by the Legislature, which enacted s. 94a (2) in 1968."' That section reads:

(2) Every affidavit intended to be used in support of an application for an interim injunction to restrain any person from doing any act in connection with a strike or lockout shall be confined to such facts as the deponent is able of his own knowledge to prove, and a copy thereof shall be served with the notice of motion.

1: 28 March 1963.

i: (1863) 40 D.L.R. (2d) 1006 at 1008 .

ix Alberta Rules of Court. R. 305.

is S.A. 1968, c. 51. S. 27. 
The writer was unable to find any indication that any attention has been given to this section by any Alberta Court. Affidavits continue to be given on information and belief despite the section. Indeed, in Calgary General Contractors v. United Brotherhood of Carpenters and Joiners Local 2103,20 an injunction was granted to restrain conduct which had not yet occurred, but which was merely feared. On the affidavit of the manager of Union Milk Company, a quia timet injunction was granted restraining all picketing at the company's premises because, although no picketing had yet occurred, the deponent believed that it was likely to begin. There was no other evidence to support this belief. It is conceivable that if the section were to be given its widest possible effect, the quia timet injunction might no longer be available in labour disputes, at least without some factual evidence to support the fear of unlawful acts. Far from giving the section so wide an effect as to prohibit quia timet injunctions, the Courts do not seem to have given it any effect at all.

Some relief from this situation might be provided by the Alberta Rules of Court, which authorize ${ }^{21}$ cross-examination of a deponent on his affidavit. The cross-examination is carried out in the same way as an examination for discovery, and no order is necessary if the deponent is within the jurisdiction. This procedure has been used many times in the past in labour cases to test the accuracy of affidavit evidence. It is not a complete answer to the criticisms expressed above, however, because the examination takes place out of Court, usually before a Court Reporter. The judge is thus denied any advantage he might have in assessing credibility from seeing the witness in the stand. Furthermore, recent judicial opinion is against the view that this procedure is available as of right. In Pulp and Paper Workers of Canada v. Modern Packaging Company,": Milvain C.J.T.D. refused to delay the application to allow examination of the affidavits; this finding was followed by O'Byrne J. in MacMillan-Bloedel Packaging Limited v. Pulp and Paper Workers of Canada.": Although these decisions are correct in recognizing the urgency involved in a labour dispute, it is submitted that they add to the problem outlined above.

It is not unfair to either labour or management to assert that the conflict and animosity of a labour dispute lead in most cases to an exaggeration of claims on both sides. This is true in the most restrained of court proceedings even when the incident giving rise to the proceedings is long over; where the picket lines are still out and the strike or lockout is still in progress, the temptation to make the evidence sound better than it should is stronger still. This problem is one of human nature for which the law generally provides through the devices of crossexamination and vica voce evidence, by which the evidence is tested and the Judge is given an opportunity to assess credibility. The labour injunctions are perhaps the only relief given by the law where the effect of the relief is so great and the evidentiary protections of the rights of the party being relieved against are so inadequate. It is submitted that this is another area in which reform of the law is essential to ensure that justice is done.

In Unreported. Supreme Court of Alberta, J.D.C. 94301, Oct. 29, 1968.

a1 R. 314.

:: Unreported. Supreme Court of Alberta, J.D.C. 97061. Nov. 7. 1969.

is Unreported. Supreme Court of Alberta. J.D.E. 64084. Feb. 16. 1970. 
The Form of the Injunction

A third criticism of the use of the injunction is that it cuts far too wide a swath, restraining activity that is perfectly legal in some cases, restraining illegal activity that had never occurred and was never intended in others. This is, it is submitted, the area in which the most blatant abuses of the law occur, and the area in which the Court most often, consciously or unconsciously, casts itself in the unsavoury role of strikebreaker. A survey of some of the cases of the past decade will demonstrate the basis of this assertion.

\section{a. The Blanket Injunction}

The blanket injunction is, of course, the most effective sanction available to the Court. A complete ban on all picketing effectively removes from the Union all its means of exerting economic pressure on the employer, and is a most potent strikebreaking tool. Fortunately, the injunction is now seldom granted in this form except where the strike is itself illegal. Picketing in support of an illegal strike has been held to be unlawful per se in Alberta, despite the declaration to the contrary of the Supreme Court of Canada in Williams v. Aristocratic Restaurants (1947) Limited. ${ }^{24}$ In Bennett and White Alberta Limited v. Van Reeder, ${ }^{2.5}$ the Appellate Division distinguished the Aristocratic case on the grounds that inducement of breaches of contract alleged in the Alberta case was not present in Aristocratic, but the actual effect of the case was to find picketing illegal where no legal strike existed.": Since then, s. 95 of the Labour Act has been amended to prohibit picketing in support of an illegal strike. The difficulty with the practical application of the law to an injunction application is that the legality of the strike may be difficult to assess. A blanket injunction based on a shaky foundation of affidavit evidence has the effect of resolving the issue immediately without adequate protection for the rights of the party enjoined.

For example, in Sheftel v. McHardy and Moore, ${ }^{2 i}$ the validity of the certification of the Union to the new management of the Empress Hotel in Calgary depended on whether the new owners had bought the land and building and set up their own hotel, or whether they had bought the hotel business from the previous owners. In the former case the certification of the Union to the former owners would be of no effect as against the new owners; in the latter case, the certification would be binding against the new owners by virtue of $s .74(1)$ of the Labour Act. Since the owners had negotiated for the purchase of the business, but then had purchased the land and buildings at a public auction, there were valid arguments on both sides of the issue. Nevertheless, Riley $\mathrm{J}$. granted a blanket injunction against all picketing ex parte solely on the evidence of the owners. During the seven days that elapsed before the injunction was vacated, ${ }^{2 y}$ the effect of that order was to prejudge the issue of the legality of the Union's claim to be the certified bargaining agent.

The blanket injunction has also been a popular order in cases where there is an allegation of secondary picketing. Secondary picketing is

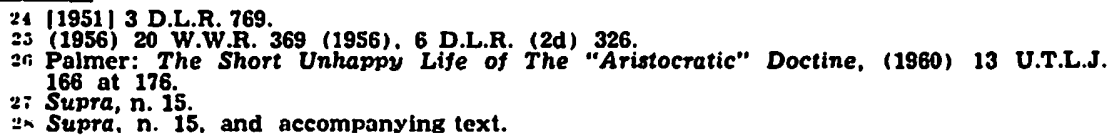


almost certainly unlawful per se in Alberta, since the Courts have applied the reasoning of Hersees of Woodstock v. Goldstein, ${ }^{20}$ the leading Ontario case on product picketing, to cases which fall far short of the facts of that case. In North Fork Timber Co. Ltd. v. Local 1-206 International Woodworkers of America, ${ }^{30}$ the Union, which was certified to Blairmore Sawmills Limited but not to North Forks, picketed during a legal strike against Blairmore at the entrance to a logging road common to both mills. A blanket injunction prohibited all picketing, despite the fact that there was no evidence that the picketing was anything but peaceful and no evidence that it was directed at North Forks, on the rather novel basis that because a breach of contract by North Forks employees had occurred, then it was reasonable to assume that the breach had been intended by the picketers. The problem of this case is that there were some arguments in favour of the legality of the picketing that were never considered, since the strike ended before any final determination of the issues could be had at trial. Five shareholders common to both companies held a majority of the shares in both of them, and four of five of the directors in each company were common to them both. In addition, there were allegations that North Forks had taken over some of the production of Blairmore during the strike. It might have been that, at trial, the rudimentary "ally doctrine" later developed by Riley J. in Standard Engineering and London House Properties v. United Brotherhood of Carpenters and Joiners, Local $2103^{31}$ would have rendered the picketing legal as against both Blairmore and North Forks. Because of the blanket injunction, however, the Union was forced to settle the strike without the economic advantage that picketing would have given it, and without any final determination on the merits of the legality of the picketing.

The most difficult picketing problem to resolve is the common situs situation, where a legal strike against an employer exists, but picketing that employer is impossible without some harm being done to other businesses occupying the common site. The least reasonable solution to the problem is the blanket injunction, used in the Super $S$ Drugs case ${ }^{32}$ and the Foundation Properties case. ${ }^{3: 1}$ Fortunately, the Courts have not used the blanket injunction in such cases with any regularity. Instead, the usual solutions have been a selective injunction, prohibiting only certain conduct, or conduct in certain areas; or a conditional injunction, permitting picketing if certain conditions are complied with; or a combination of these two.

\section{b. The Selective Injunction and the Conditional Injunction}

A good example of a selective injunction is found in COMINCO and Kootenay Engineering v. Local 254 International Brotherhood of Electrical Workers:: 1 There, Kootenay was engaged in construction of a new fertilizer plant on COMINCO's premises in Calgary during a

2!! (1963) 38 D.L.R. (2d) 449.

:10 (1964) 45 D.L.R. (2d) 79. (1964) 48 W.W.R. 498.

:1 Unreported. Supreme Court of Alberta. J.D.C. 94342, Nov. 4, 1968. In this case, when Cascade Bullders were struck by the Union, the contract for the job was transferred by London House to Standard. Riley $\mathrm{J}$. refused an injunction to restrain picketinis against Standard. finding that Cascade and Standard were commonly owned and managed and were not at arm's length. The case is simitar to United States decislons permitting secondary picketing against companies which go to the assistance of the employer by taking over production, etc.

i: Supra, n. 12.

33 Supra, n. 13. 
strike by the Union against COMINCO. The new plant was separated from the remainder of COMINCO's land by a high wire fence, and Kootenay's employees gained access to the work site by a separate gate. When the Union picketed both entrances and Kootenay's workers refused to cross the picket lines, the Court granted an injunction restricting the pickets to the entrance to the COMINCO plant proper. A similar solution was applied in Nichol v. MacLaren, ${ }^{3 \pi}$ where a strike against the hotel adversely affected the business of a barber shop and restaurant leasing space from the hotel. The injunction order permitted picketing of the hotel, but restrained picketing along the street in front of the restaurant and barber shop. A balance of convenience was struck in this case to uphold the lawful picketing without unduly harming the business of persons not parties to the strike.

Nichol v. MacLaren also marks the beginning of a unique form of conditional injunction by which picketing is permitted on condition that the picket signs carry some sort of exhortation to the public or to other unions. In the Nichol case, the order granted by Riley J. simply said:

"Any placard, banner. or in fact any communication, written or oral, should make it clear, and not in fine print, that the plaintiffs' premises are not being picketed."

This order, as it stands, is unobjectionable. It permits continued picketing, and does not allow the picketing to be restrained simply because some harm is incidentally done to third parties when that harm may be avoided or minimized without affecting the force of the picketing. Later applications of the principle are not, however, quite so acceptable.

An extension of the principle came in Calgary General Contractors v. Local 40, Canadian Union of Public Employees.": There a strike by union employees of the Calgary School Board resulted in picket lines being formed around schools at which construction was being carried out. When members of the construction trades unions refused to cross the C.U.P.E. picket lines, the contractors sought an injunction restraining all picketing. Milvain $J$. (as he then was) decided instead to restrain picketing only at certain schools and at certain entrances at other schools. In addition, he later amended the order to require picketers at one school where construction workers still refused to cross the picket lines to carry signs with the following exhortation added to the wording:

"We desire that the employees of any other employer working on this job site continue to work."

In the following year, the same condition was imposed on picketers in the Construction Trades dispute in both Edmonton and Calgary. In Calgary General Contractors v. United Brotherhood of Carpenters and Joiners, Local 2103,3i and in Edmonton General Contractors (Smith Bros. \& Wilson et al.) v. United Brotherhood of Carpenters and Joiners, ${ }^{3 \mathrm{~N}}$ the following addition to picket signs was required as a condition of permitting picketing:

"We desire that all employees on this job who are not on strike continue to work." (Calgary)

"We desire employees or suppliers on this job to continue to work." (Edmonton)

In Calgary, the lettering was required to be black and at least four

:5i (1865) 51 D.L.R. (2d) 667.

:1: Unreported. Supreme Court of Albrta, J.D.C. 30258, Aug. 31, 1967, order amended Sept. 1, 1967.

:: Supra, n. 20.

:\# Unreported. Supreme Court of Alberta. J.D.E. 59501. Nov. 1. 1968. 
inches in height; in Edmonton, the lettering was only required to be two inches in height.

Used in this way, the principle of permitting conditional picketing undercuts the entire advantage the unions might have gained from the increasing reluctance of the courts to grant blanket injunctions in common site cases. The Courts still have not accepted the principle that the legislative recognition of the trade union movement and legislative sanction of strikes as an incident to collective bargaining must, if they are to mean anything at all, mean that legislative approval is also given to economic pressure as a valid method of waging the contest. It is true that not all acts which are sometimes connected with picket lines have been approved by the legislature, but it must also be true that peaceful picketing has been approved. Picketing depends for its effectiveness on bringing pressure to bear on the employer, and that pressure is brought by persuading the public not to do business with him and, if possible, persuading his other employees not to work for him. If picketing cannot achieve at least some of these objectives, then there is little point in picketing at all, and the only method by which the union may bring pressure to bear on the employer is by withdrawing the services of its members. The pressure that an employer may exert on the union if the services of the union members are not required for his operation to continue is considerable, even when his production efficiency is reduced by their absence. He may continue production at a reduced level and refuse to negotiate reasonably with the union; the union members, without any means of support and without a strong financial base from which to resist the rigours of a long strike, are son driven to accept a bargain that they would not have considered were they able to take full advantage of union solidarity and public support.

\section{c. The Sweeping Injunction}

In an editorial comment on the injunction granted in the Calgary General Contractors case, the Edmonton Journal said: ::"

"As it is, the decision is puzzling incleed. Inasmuch as the acknowledged purpose of picketing is the peaceful dissuasion of others, $\mathrm{Mr}$. Justice Riley's decision would seem to place the unions involved in this dispute in a position where they must deny their obvious and quite legal purposes.

"Outside of ordering all pickets removed from the Calgary work sites, it is difficult to see what more could be done to render lawful picketing impotent."

What more could be done to render lawful picketing impotent could be found in the same issue of the Journal, for on that same day an injunction had been granted in the Edmonton General Contractors case that far surpassed the Calgary order in scope. The entire text of the order is reproduced below. It should be read with the facts in mind that the affidavits filed disclosed only that some members of other unions had refused to cross the picket lines, that certain unions provided fines in their by-laws for any of their members who crossed a picket line recognized by the union, and that the Building Trades Council had encouraged its members not to cross the picket lines. In addition, there was evidence of one incident in which a subcontractor had been stopped by the pickets and threatened; the allegation was vigorously denied by the union's affidavits. Based on such evidence, the following order was granted:

$: \because$ November 1, 1968. 


\section{IT IS HEREBY ORDERED THAT}

1. The Defendants, their scrvants, agents, cmployees, successors and anyone on their behalf, be restrained from

(a) Carrying any picket signs whatsoever or howsoever near any of the construction projects of the Plaintiffs herein, except provided that in large black letters of at least two (2) inches in height, the said picket signs, after declaring that the Union is on strike, state further:

"We desire employees or suppliers on this job to continue to work."

2. The Defendants, their servants, agents, cmployees, successors and anyone on their behalf, be restrained from

(a) Causing adjacent to, of in the vicinity of the premises on which any of the Plaintiffs carry on construction projects, a nuisance and particularly, from conduct likely to attract groups of persons adjacent to the premises or likely to deter persons with peaceable or lawful objects, from approaching, viewing, entering or leaving the said construction premises.

(b) Watching or besetting, or procuring to be watched and beset any premises on which any of the Plaintiffs carry on construction projects, save and except as provided in (f) below.

(c) Molesting. threatening or intimidating and from attempting to molest, threaten or intimidate the cmployees of the Plaintiffs herein, customers of the Plaintiffs, and other persons attending at or in the vicinity of the construction projects of the Plaintiffs herein, for the purpose of doing work for, or business with, for, or on behalf of the various Plaintiffs herein, and from discouraging or preventing or attempting to discourage or prevent, any person from doing business or work with, or for or on bahalf of the Plaintiffs herein, and from, in any manner, detering or attempting to detcr, persons with peaceful or lawful objects, from approaching, viewing, entering or leaving the said premises.

(d) Conduct injurious to the business of the Plaintiffs herein and from unlawful assembly on the sidewalk or roadways leading to the various construction projects of the Plaintiffs herein.

(e) Interference, physical or otherwise, with vehicles approaching the various job sites of the Plaintiffs herein, or interfering with the drivers or passengers in such vehicles.

(f) Acting as pickets at or near the following construction sites of the following General Contractors, with the exception that onc picket will be entitled to patrol each side (a curved side to be considered as one side) of the construction site, but the said picketers shall not be entitled to picket within fifty (50) feet of either side of any construction or other entrance to the construction site; provided wherc a side of a construction site is less than 100 feet that the fifty feet be reduced by the same percentage that the side of the . site is less than the 100 feet. ....

[a list of construction sites follows]

Considering the state of the evidence this injunction covers entirely too wide a scope. The injunction restrains conduct that, at least according to the affidavits, had not yet occurred and was not reasonably feared. Furthermore, it restrains conduct much of which is already adequately covered by the criminal law or which is redressable under the law of tort. What the court has done here, in effect, is to create a new code of behaviour applicable to the circumstances of this strike only, and to attach to that code the sanctions of the contempt power of a court of Equity.

It appears entirely unnecessary to restrain conduct already criminal by its nature by including it in the terms of an injunction. Furthermore, such a course of action is wrong in principle. The striker who defies the injunction is theoretically put in double jeopardy because he is liable to punishment both under the criminal law and for contempt of court for one single criminal act. He is moreover not entitled to the same procedural protections when being punished for contempt of court that are guaranteed to him when he is being punished for the same offence under the criminal law. In an American case dealing with a similar injunction, the court said: ${ }^{\prime \prime}$

The Penal Law is a standing injunction against crime ... If the defendants

in Wood Mouing \& Reaping Company v. Toohey, 114 Misc. 185 at 196 (N.Y. 1921). 
are committing crime, the quick, summary, regular remedy is arrest and prosecution.

There is also considerable danger in the practice of including in this code of conduct behaviour which, apart from the injunction, would not be criminal or tortious in nature. The result is to deny to the strikers rights which they seem to have been intended to have by the Labour Act and by the Criminal Code. There seems to be no good reason why, if the Labour Act is silent as to the number of picketers allowed along each side of a job site, or as to the distance within which these picketers may approach the entrances, the Court should be the proper body to lay out a code of hehaviour based almost entirely on what has been done in previous cases and what is suggested by Plaintiff's counsel. In this area the Courts, normally slow to embellish legislative pronouncements, are actively engaged in legislating. This is not a case of settling the rights of parties after the event. It is rather a case of creating new rights for the parties at the very outset of the dispute; making law for them, as it were. This sort of practice gave rise to a widespread reaction in the United States at about the turn of the century against what was called "government by injunction". In an article written in 1897, the matter was treated as a violation of the authority of the legislative arm of government: ${ }^{11}$

Courts of equity, like courts of law, are established for the determination of controversies between individuals. The power to issue preliminary injunctions is incidental to the power of determining such controversies. The right to lay down general rules for the government of the community, to declare ex cathedra, in advance of any contentious proceedings in which the question arises, what may and what may not lawfully be done, to impose on the whole community a duty to refrain from doing a certain act, is in its nature a legislative right.

The dividing line between judicial and legislative authority is of necessity a very fine one, but the Construction Trades dispute clearly indicates that the courts have crossed that line. The limiting of the number of picketers at any site would be unobjectionable in any case where mass picketing had occasioned breaches of the peace or where there was reasonable fear that mass picketing was intended and that if it occurred breaches of the peace would be likely. Where, however, the affidavits disclose no incidents of mass picketing, and the picketing has been peaceful, an order limiting the number of picketers is an unjustified assumption by the courts of a legislative power if done consciously, and evidence that injunctions are granted perfunctorily if done without any consideration of the degree to which the court is arrogating to itself the power to create the law governing the relationship between the parties. Thus, in the Calgnry General Contractors case, where the affidavits on both sides disclosed that no more than four picketers had paraded at any one job site at any one time, and the photographs attached to the affidavits indicated that one lone picket was the usual case, there could be no justification for any order limiting the number of pickets. Equity follows the law, and before there can be an injunction at equity there must be a right in law. Parading by four pickets is no tort, nor is it a crime. If intimidation is the tort that is complained of or reasonably feared, then it can be restrained; if breaches of the peace are reasonably feared, they also can be restrained. But, in the absence of any legislation governing the number of pickets who may patrol at a job site, a direction to that effect by

11 Dunbar, Government by Injunction, (1897) 13 L.Q.Rev. 347 at 362. 
the courts is quite plainly government by injunction. Nevertheless, limitation of the number of picketers is now done routinely by the courts in Alberta whether or not there is any justification for such extraordinary exercise of the judicial power.

It must be noted that, although the sweeping injunction has become commonplace in Alberta, there has recently been some activity on the part of the Courts to ensure that the effect is not totally to eradicate the right to strike or the effectiveness of that right. In MacMillanBloedel Packaging Ltd. v. Pulp and Paper Workers of Canada Local 16,"' O'Byrne J. added to a restraining clause almost identical to clause 2 (a) in the Edmonton Contractors injunction quoted above a proviso in the following terms:

.... provided that the Defendants may peaceably persuade the public or employees or prospective employees of the Plaintiff.

and a similar proviso was added to a clause almost identical to clause 2 (c) above. This proviso goes a long way toward creating a judiciallyauthorized right of peaceful picketing, and although it is open to the same criticisms as above as judicial legislation in that it is issued before the event to regulate the relations between the parties, it nevertheless embodies the right to picket formulated by the Supreme Court of Canada in Williams v. Aristrocratic Restaurants (1947) Limited. I: In MacMillanBloedel Packaging Ltd. v. Pulp and Paper Workers of Canada Local 14," this time a case involving the Calgary branch of the company, Milvain C.J.T.D. was less prepared to leave the union with a right to persuade the public. The proviso which he included in the same places in the order read

.... provided that the picketers may peacefully convey to the public, employees and prospective employees information as to the strike.

\section{d. The Quia Timet Injunction}

The injunction has occasionally been made available to a party to a labour dispute before any damage has been suffered and even, in some cases, before there has been a strike. The quia timet injunction, carefully used, is an essential part of the benevolent jurisdiction of equity, designed to restrain imminent illegal acts before they can be committed when their commission is likely to cause irreparable damage. In the past, as has been noted above, ${ }^{+:}$they have been granted on little more evidence than an expression of anxiety by the plaintiff.

A recent labour dispute indicates that such perfunctory injunctions are now less easily obtained. In City of Lethbridge v. Glassworkers Union Local 1725,": the city applied for an injunction to protect vital city services from picketing even before the Union had gone on strike. Cullen $J$. noted that the basis for the quia Timet injunction was a demonstration by the plaintiff of a strong case of probability that the apprehended mischief would actually occur. He was unwilling to infer that the delivery of strike notice by the union constituted proof that certain vital services would be shut down by picketing, although he was of opinion that such a shutdown would be enjoinable once it had occurred. 
Immediately following the commencement of the strike, the City again applied for an injunction, ${ }^{17}$ this time alleging inducement of breaches of contract and watching and besetting, and once again raising the spectre of a shutdown of vital services despite the union's forbearance to picket such installations as the power station, waterworks and sewage plant. Sinclair J. noted, correctly it is submitted, that the Labour Act provided an emergency procedure in s. 99, and declined to enjoin picketing that had not yet occurred when the apprehended result of that picketing was specifically provided for in the Labour Act.

Although an injunction was granted restraining certain union irregularities on the picket lines, the main part of the judgment correctly categorized the injunction as an extraordinary remedy and rightly refused a quia timet injunction to restrain activity that was both improbable and otherwise provided for in the Labour Act.

\section{Policy Considerations}

Much of the above criticism of the labour injunction has been based on the specific procedural abuses to which the injunction is susceptible, and the procedural flaws inherent in the use of a remedy designed for entirely different circumstances than those encountered in a labour dispute. In the end, however, the critical question to be answered is one of policy: to what extent does society wish to accept the consequences of the organization of labour when those consequences conflict with the established theories of law and property? In the words of Mr. Justice Holmes: "s:

.... in all such cases the ground of decision is policy; and the advantages to the community, on the one side and the other, are the only matters really entitled to be weighed.

It is submitted that the Courts of this province are not the place to decide policy for the labour movement, its progress or its control. The courts are in general congenitally unsuited to make policy decisions in this area, not because the judges are incapable of appreciating the problems involved nor even, as many writers in this area have suggested, because judges, as lawyers, are educated to uphold the capitalistic free enterprise system of another century and another political reality. The real reason is that courts are set up to administer the law, and the law is dedicated to the resolution of conflicts, the maintenance of the peace, and the preservation of property in its widest sense. Law abhors conflict and struggle, and exerts its tremendous power to the end that conflict is always resolved with words. The strike, the picket line, the raised voices and the rhetorical excesses that accompany labour disputes run contrary to the legal concepts of order based on the rule of law, and as a result, the courts are quick to seek a solution in precedent and reason. But the problem is not a static one, involving the determination of the rights of the parties according to the established rules by which the game has always been played and must now be played. Rather, a dynamic situation exists in labour disputes, one in which raw power is exercised by the parties to force the opponent to his economic knees. The courts are not unused to the exercise of economic pressure, of course, but the areas in 
which it has historically occurred, such as contract law, are now so highly ritualized that the contest more closely resembles a chess game than a battle. The difficulty is that the rituals do not travel well into the area of industrial negotiations.

Our society has accepted the challenge of organized labour and has accepted the principle that industrial conflict is an acceptable phenomenon in our way of life. This does not, unfortunately, determine the matter.

Recognition of the social utility and, indeed, of the necessity of trade unions implies acceptance of the social and cconomic pressure that can come from united action. Such acceptance does not solve all difficulties; it leaves open the most troublesome of questions-the questions of how far and when. The possible ramifications that the power of concerted action may take and the various uses to which it may be put raise bristling questions of policy, and, therefore, of law."!!

The legislature in this province has effectively answered the question of when economic pressure may be applied; it has been derelict in its duty to decide, in the public interest, how much pressure can be applied. In leaving this decision to the courts, the legislature has encouraged the situation which now exists and which has been illustrated by the cases studied above. The result has been to foster unnecessary industrial unrest, alienate the respect of a sizeable proportion of the community for the courts, and generally derogate from the authority of the law by expecting of it that which it cannot provide: a political balance of convenience for the benefit of the whole society.

\section{Recommendations for Reform}

The responsibility for much of the difficulty with the labour injunction lies with the legislature; it therefore follows that only legislative action can remedy the faults of this area of the law. At the outset, it should be stated that the popular reform suggestion in the labour movement, complete abolition of the injunction in labour cases, cannot be supported. First, no society can afford to rid itself of the power to prevent, by judicial action, conduct which is actually or potentially dangerous to persons or property. Second, the injunction has been used to advantage by labour as well as management, and will continue to be of great importance to industrial relations for so long as conflict exists. In Alberta, unions have used the injunction to restrain unfair labour practices, for which the penalties provided in the Labour Act are laughably small and the sentences actually awarded by the courts even smaller. In Truckers, Cartagemen, Construction and Building Material Employees, Local 362 v. Midland Superior Express Limited, alteration of wages and working conditions by the employer during the currency of collective bargaining contrary to the Industrial Relations and Disputes Investigations Act," s. 14 (b) was enjoined. In Truckers, Cartagemen, Construction and Building Material Employees, Local 362 v. Richardson Transport, i" where certification problems were complicated by the existence of a company-dominated union and adamant management, an injunction issued to protect the employees from dismissal except for just and reasonable cause. In Driver Salesmen, Plant, Warehouse and Cannery Employees, Local 987 v. Board of Industrial Re-

4! Frankfurter and Greene. The Labour Injunction, (1963, 3rd printing) at 204

$\therefore$ Unreported. Supreme Court of Alberta, J.D.C. 92520, Apr. 4, 1968.

i1 R.S.C. 1952. c. 152.

$\$ 2$ Unreported. Supreme Court of Alberta, J.D.C. 95466, Apr. 9. 1969. 
lations, ${ }^{53}$ the union succeeded in enjoining the Board from taking action not authorized by the Labour Act. The injunction has also been used against other unions, and has been particularly in evidence in Quebec during the jurisdictional struggle between the Canadian Labour Congress and the Confédération des Syndicats Nationals." Although the labour movement would likely give up readily the small advantages it has gained from the existence of the injunction to be rid of it, the community at large cannot afford that luxury. The correct solution is not abolition of the injunction, but careful circumscription of its use to take full advantage of its adaptibility to labour disputes and avoid the abuses to which it is prone in its present form.

The first step in the rehabilitation of the labour injunction must be a clear and unmistakable declaration of public policy with respect to the rights of workers, whether on strike or not, to exert economic pressure through collective action on their employers. Such a declaration must spell out the right to strike and to picket, and must also determine the limits of those rights. It is not enough to leave the establishment of the bounds of lawful picketing to the criminal law and to the law of tort. The former is impossibly obscure; no court has ever been able adequately to define the expression "watching and besetting" in s. $366(1)(f)$, of the Criminal Code, except to say that certain conduct does or does not fall within the section. The latter is hopelessly bound up with concepts that are inapplicable to the labour situation, or were expressly invented by the English courts out of an exaggerated concept of property and an animosity for the aspirations of the labour movement."in It is beyond the scope of this article to deal with the details of the law of picketing, which have been adequately covered elsewhere, but it is essential to note that any reform of the law of the labour injunction depends upon a re-evaluation of the policy considerations behind the law of picketing and a redefinition of the bounds of lawful picketing. Without such a redefinition, the power of the injunction will grow once again out of control; it is a remedy which expands rapidly to fill vacuums in the law, and unless the vacuums are filled with soundly reasoned and politically responsible declarations of policy, they will be filled instead with generalizations drawn from solutions reached ad hoc in circumstances of urgency and without benefit of thorough argument. Without legislative definition, in short, the law of picketing will continue to be based on an eclectic appeal to precedent rather than on a coherent application of policy.

There is some evidence that the Legislature is prepared to take some steps in this direction. The latest amendments to the Labour Act"it include new section $94 \mathrm{~b}$, which establishes for the first time in the province that there is a right to lawful picketing during a lawful strike. The section provides:

94b. (1) Where there is a lawful strike or lockout, a trade union, members of which are on strike or locked out, and anyone authorized by the trade union may, at the striking or locked out employec's place of employment and without acts that are otherwise unlawful, persuade or endeavour to persuade any one not to

::: (1967) 61 W.W.R. 484.

i) Cimon, L'Injonction dans le monde du travail, (1966) 26 R. du B. 417.

$\therefore$ In support of this proposition. see Wedderburn. Strike Law and The Labour Injunction: The British Experience: 1850-1966, in Carrothers and Palmer. Report on a Study of the Labour Injunction in Ontario. (1966. mimeo, Toronto) 605 at 611-616.

$\therefore$ S.A. 1970, c. 63, s. 52. 
(a) enter the employer's place of business, operations or employment, or

(b) deal in or handle the products of the employer, or

(c) do business with the employer.

The second subsection restricts these rights to the conditions set out in subsection (1).

This provision, of course, does not meet the requirements set out in the preceding paragraphs; it is possible that it does not change the law as it was before the amendment in any appreciable way. It is, however, a step toward a solution, and is indicative that the legislature has grasped the significance of decisions in the law of picketing which, if carried to their logical conclusion, would effectively emasculate picketing as a weapon in labour disputes.

The second step required in reform of the law is to remove the power of the injunction in labour cases from the courts and lodge it with a body more attuned to the circumstances of industrial disputes. The most loyal supporter of the courts will find it difficult in the face of the cases discussed above to absolve the courts from every suspicion of an anti-labour bias. To a large extent, this bias is inherent in the law which the courts are required to apply: but some blame must also lie with the judges themselves. It is the law which recognizes a property right in the employer's contractual hold on his non-striking employees, but refuses to recognize a correlative property right in the interest of the workers in the jobs which they held prior to the strike when these jobs are threatened by strikebreakers. On the other hand, the courts must take full responsibility for the continued acquiescence in ex parte applications long after clear legislative direction to the contrary. The unfortunate fact is that the courts no longer have the confidence of organized labour. Sir Winston Churchill remarked in 1911: :i

It is not good for trade unions that they should be brought into contact with the courts, and it is not good for the courts. The courts hold justly a high and I think unequalled prominence in the respect of the world in criminal cases, and in civil cases between man and man, no doubt they deserve and command the respect and admiration of all classes in the community: but where class issues are involved it is impossible to pretend that the courts command the same degree of general confidence. On the contrary, they do not and a very large number of our population have been led to the opinion that they are. unconsciously no doubt, biased.:

It is submitted that the same situation obtains in Alberta, and indeed, everywhere in Canada, today.

It is worthy of note that both the Rand Royal Commission" and the Woods Task Force: have taken the approach that the injunction power should be removed from the courts and given to a labour relations board. Both reports indicated that it was considered that the policy behind the labour relations legislation could be better implemented by an administrative tribunal composed of members selected for their expertise in labour relations than by a court exercising its general equitable jurisdiction. I respectfully adopt that conclusion, adding only that the respect of both labour and management is less likely to be alienated from such a tribunal. As noted in the Rand Report, a constitutional problem arises from the requirement that judges be appointed by the Federal Government under section 96 of the British

$\therefore$ - Parl. Deb. May 30. 1911. H.C.. quoted in Wedderburn. supra, $\mathrm{n} .55$ at 619-620.

$\therefore$ Province of Ontario. Royal Commission Inquiry into Labour Disputes, 1968, Quecn's Printer. Toronto, 1968, at 81.

s. Canada. Privy Council. Canadian Industrial Relations, Report of the Task Force on Labour Relations. Queen's Printer, Ottawa, 1968, at 185-187. 
North America Act. This is an important consideration when, as here, a provincial labour relations board is involved. There seem to be two solutions to this problem. The first is to define the bounds of legal picketing with great care in the Labour Act, and then give jurisdiction to the Board to set, on application by either party to a strike, the conditions under which picketing may be carried out. Similar definition and vesting of jurisdiction would also be necessary in all the other areas where the injunction might be of value in labour relations. The Board could then be authorized to make restraining orders, enforceable by the court on application by the Board. All other jurisdiction of the Court to grant injunctions in respect of a labour dispute would be ousted by statute. The second solution is that proposed by the Woods Report-joint Federal-Provincial action to constitute a labour court for the provinces to hear labour cases subject to either Federal or Provincial legislative authority. Either of these solutions would be acceptable; the former seems more feasible in the light of present Federal-Provincial relations.

The final stage in the reform of the law is the reform of the procedural defects of the injunction application. Since the dynamics of labour disputes require a quick remedy, and since it is desirable to have a final and binding decision on the merits of the case as early as possible, it would be best to have one hearing only on the issue, subject to appeal in the usual form. That hearing should inevitably be on notice to all interested parties, and provision should be made for service of notice on both employers and unions at their offices or on an officer or responsible agent. It would be desirable to require unions to establish an address for service in order to expedite applications and hearings. Notice of twenty-four hours would be sufficient, but a solitary exception should be made to the rule against ex parte proceedings to permit a party to obtain a temporary restraining order valid for twenty-four hours only on ex parte application where it is alleged by evidence on oath that injury to persons or physical damage to property has occurred or is imminent. Because of the objections to affidavit evidence noted above, the hearing of the application should be an open hearing of viva voce evidence given on oath and subject to cross-examination. In this way, all the evidence would be subject to an assessment of credibility by the tribunal. and would be subject to testing by crossexamination by the opposite party. It is submitted that a single open hearing of the issue in the presence of both parties is the only way in which any reasonable guarantee of the justness of the order can be given.

Further, the tribunal should come to a decision on the facts as alleged, and should preface any order made by a summary of the facts found and in reliance on which the order is issued. This would always be the procedure in the trial of a case under the present law, but such a program is never followed on an interlocutory application where the court must be especially careful not to prejudge the facts. Since the recommended procedure would only authorize the granting of an injunction after the final determination of the issue, it is essential to come to a final determination on the facts as well.":"

iin Norris-LaGuardia Act. 47. Stat. 70, as amended, 29 U.S.C. Sec. 101. S. 59 covers this point. and several other sections influence the other proposals made below. 
Finally, certain conditions should be set out which must be met before any restraining order may issue. The recommended conditions are set out below.

(1) No restraining order should be granted to restrain or restrict any right affirmed by the codification of the law of peaceful picketing. This would ensure that the tort concepts that these reforms are designed to abolish from the law of industrial disputes do not creep back into the law to abridge the right to wage an economic contest as a part of the bargaining process.

(2) Only acts which are unlawful in themselves or which are unlawful as being contrary to an order of the tribunal made within its jurisdiction should be enjoined, and then only if it is proved that these acts have occurred and will continue if the order is not granted, or that they are imminent and will occur if the order is not granted. This still permits a form of the quia timet injunction, but only where the conduct feared is imminent.

(3) The applicant must establish that there is no adequate remedy in the common law and no adequate sanction in the criminal law to redress the wrong done to him by the conduct complained of; he must establish that substantial and irreparable harm will be done to him if the order does not issue.

(4) The order must be issued on a finding that the balance of convenience warrants the issue; specifically, it must be shown that greater injury will be done to the applicant by the denial of the relief than will be done to the respondent by the granting of the relief. This is a most important provision. Carrothers has asserted"it that in injunction cases, the choice before the court may not be between irreparable damage to one side and compensable damage to the other, as the courts seem always to have assumed heretofore; rather, because the effect on the position of the union caused by the deprivation of an economic weapon may by its nature be incalculable, the court may be faced with a choice between irreparable harm to either party. Thus it is essential that the order issue only on a finding that it is warranted by the balance of convenience, quite apart from the fact that the necessity for the order has been demonstrated.

(5) Where a temporary restraining order is granted ex parte in an emergency, the applicant must enter into a security for the damages and costs of the other party in case he should later be found not to have been entitled to the relief granted. In all other applications, the same security shall be given in case the applicant shall be found on appeal not to have been entitled to the relief claimed. This is one area where the present law is quite satisfactory. It is settled now that an abandonment of a interlocutory application before trial on the merits is an admission that there was never any entitlement to the relief granted as an interlocutory measure, and that the injury done thereby to the party restrained is compensable in damages, ${ }^{\prime \prime \prime}$ and that such damages are also available when the right is found not to exist only on appeal.:3 This proposal would preserve these safeguards of the respondent's interest.

(i) Carrothers, The Labour Injunction in British Columbia, CCH, Toronto, 1956, at 206. 


\section{CONCLUSION}

It is submitted in conclusion that the labour injunction is procedurally inadequate in the protection it offers to the party sought to be restrained, and has furthermore, because of these procedural inadequacies, been directly responsible for the introduction of error into the substantive law. The combination of these two faults has weakened the respect in which the courts are held by a large segment of society, and has put the courts in a position where social injustice and class bias have been imputed to them, whether with or without sufficient reason.

This state of affairs is due to a large extent to a lack of clear legislative direction as to the policy contemplated to be embraced with respect to the adoption of labour relations legislation. Such legislation should recognize the right to exert economic pressure through concerted action in support of the legitimate goals of the labour movement. In such circumstances, the required solution is clearly a legislative one, in which a clear guide to the policy required by the public interest is formulated, and in which the procedural shortcomings of the present law are corrected.

Rationalization and reform of the law of picketing, combined with the suggestions made above for the rehabilitation of the injunction, will preserve the value of the labour injunction without perpetuating any of its defects. Such a result will achieve both efficiency in and respect for the law. 